\title{
PENGARUH GAYA KEPEMIMPINAN, PENGETAHUAN PRINSIP DASAR PLS, DAN MOTIVASI KERJA TERHADAP KOMITMEN ORGANISASI PENGELOLA PUSAT KEGIATAN BELAJAR MASYARAKAT
}

\author{
Fakhruddin*
}

\begin{abstract}
Abstact
The objective of this research is to find out the effect of leadership style, knowledge of the basic principles of non-formal education, and work motivation on organizational commitment of Community Learning Centre (CLC) Managers in Jakarta. This research was conducted in DKI Jakarta, on March to August 2009. The data was collected from 85 managers as sample and selected by simple random sampling . The result of this research are as follows: (1). The leadership style of CLC managers has direct effect on work motivation; (2). knowledge about of basic principles of non-formal education has direct effect on work motivation; (3). Work motivation has direct on organizational commitment of CLC managers; (4). The leadership style has direct effect on organizational commitment of CLC managers; (5). Knowledge about of basic principles of non-formal education has direct effect on organizational commitment of CLC managers; (6). The leadership style of CLC managers has indirect effect on organizational commitment of CLC managers, Through work motivation and (7) Knowledge about of the basic principles of nonformal education has indirect effect on organizational commitment of CLC managers through work motivation. Therefore, it could be concluded that the increasing of or decreasing of organizational commitment effected directly or indirectly by leadership style, knowledge about the basic principle of Non Formal Education and work motivation. This conclusion implies that when we want to improve the organizational commitment, we have to take into consideration those three variables, leadership style, knowledge about the basic principle of non formal education and work motivation as well.
\end{abstract}

Key Words: leadership style, organisational committment, basic principle, working motivation

\section{Abstrak}

Tujuan penelitian ini adalah untuk menemukan pengaruh tipe kepemimpinan, pengetahuan prinsip dasar Pendidikan Nonformal, dan motivasi kerja terhadap komitmen pengelola pusat kegiatan belajar masyarakat di Jakarta. Penelitian ini dilakukan di DKI Jakarta dari bulan Maret-Agustus 2009. Pengumpulan data dilakukan terhadap 85 pengelola sebagai sampel yang dipilih secara simple random sampling. Hasil penelitian menunjukan bahwa: (1). Gaya kepemimpinan dari pengelola PKBM memiliki pengaruh langsung pada motivasi kerja; (2) Pengetahuan tentang prinsip-prinsip dasar dari Pendidikan Nonformal memiliki pengaruh langsung pada motivasi kerja; (3) Motivasi kerja memiliki pengaruh langsung pada komitmen organisasi dari pengelola CLC; (4). Gaya kepemimpinan memiliki pengaruh langsung pada komitmen organisasi dari pengelola CLC; (5). Pengetahuan mengenai prinsip dasar dalam Pendidikan Nonformal memiliki komitmen organisasi dari pengelola CLC; (6). Gaya kepemimpinan dari pengelola CLC memiliki pengaruh tidak langsung terhadap komitmen organisasi dari pengelola CLC, diluar motivasi kerja dan (7). Mengenai pengetahuan dari prinsip dasar dalam Pendidikan Nonformal memiliki pengaruh tidak langsung dalam komitmen organisasi dari pengelolaan CLC diluar motivasi kerja. Oleh karena itu, dapat disimpulkan bahwa peningkatan atau penurunan dari efek komitmen organisasi berpengaruh langsung maupun tidak langsung dengan gaya kepemimpinan, pengetahuan mengenai prinsip dasar Pendidikan Nonformal, dan motivasi kerja. Kesimpulannya yaitu bahwa ketika kita ingin meningkatkan komitmen organisasi, kita harus mempertimbangkan tiga variabel, gaya kepemimpinan, pengetahuan mengenai prinsip dasar dari Pendidikan Nonformal, motivasi kerja dengan sebaik mungkin.

Kata Kunci : gaya kepemimpinan, komitmen organisasi, prinsip dasar, motivasi kerja, pengelola 


\section{PENDAHULUAN}

Pendidikan diharapkan dapat menjawab berbagai tantangan kehidupan manusia, baik yang diakibatkan oleh faktor lingkungan maupun faktor alam, yang kurang bersahabat, sering memaksa dan mendorong manusia untuk mencari cara dan jalan yang memungkinkan mereka untuk keluar dari kesulitan yang dialaminya. Kesadaran masyarakat untuk tidak melanjutkan pendidikan yang memungkinkan dalam menggeluti profesi tertentu juga masih rendah. Hal ini menuntut upaya dan usaha dari pemerintah untuk membantu masyarakat mewujudkan potensi-potensi yang ada pada dirinya agar dapat bermanfaat untuk pembangunan dirinya dan sekaligus bangsanya.

Program pendidikan luar sekolah (pendidikan nonformal) yang berbasis masyarakat mempunyai peranan yang sangat penting dan strategis serta berkelanjutan untuk meningkatkan kualitas (mutu) dan daya saing sumber daya manusia Indonesia. Eksistensi pendidikan luar sekolah pada dasarnya mengacu kepada prinsip pendidikan seumur hidup yaitu kepercayaan bahwa belajar terjadi seumur hidup (sepanjang masa) dan tidak pernah berhenti. Prinsip pendidikan seumur hidup dilakukan dengan cara yang berbeda dan melalui proses yang tidak harus sama di semua tempat atau wilayah. Prinsip pendidikan seumur hidup dapat memberikan jawaban bahwa kontribusi pendidikan luar sekolah amatlah besar dalam pembangunan bangsa ini. Pendidikan luar sekolah berkontribusi terhadap pencapaian tujuan pembangunan pendidikan. Pendidikan nonformal ini juga merupakan pendidikan alternatif yang memungkinkan pembangunan pendidikan lebih berhasil dan berdaya guna.

Data perkembangan Pusat Kegiatan Belajar Mengajar (PKBM) menunjukkan PKBM yang berada di 5 wilayah DKI Jakarta, berjumlah 170 PKBM, yang terdiri dari 140 PKBM swadaya dan 30 PKBM negeri. Wilayah Jakarta Barat berjumlah 56 PKBM, 51 PKBM swadaya dan 5 PKBM negeri. Wilayah Jakarta Timur ada 49 PKBM terdiri dari 41 PKBM swadaya dan 8 PKBM negeri. Wilayah Jakarta Pusat jumlah total 26 PKBM, 20 PKBM swadaya dan 6 PKBM negeri. Wilayah Jakarta Selatan terdapat 18 PKBM, ada 9 PKBM baik swadaya dan 9 PKBM negeri. Wilayah Jakarta Utara beriumlah 21 PKBM, 19 untuk PKBM swadaya dan 2 PKBM negeri.

Program PKBM di Propinsi DKI Jakarta memiliki karakteristik sendiri dan arah programnya disesuaikan dengan permasalahan-permasalahan yang tumbuh dan berkembang di lingkungan masyarakat perkotaan.
Pengelolaan PKBM di DKI Jakarta dikelola oleh pemerintah dan oleh swadaya masyarakat. Secara filosofis sebenarnya kehadiran PKBM adalah dari, oleh dan untuk masyarakat. Pertumbuhan dan perkembangan PKBM seharusnya muncul dari inisiasi dan partisipasi masyarakat itu sendiri, sedangkan pemerintah termasuk pemerintah daerah hanya membuat regulasi dan melakukan pembihaan dalam hal standar-standar mutu untuk semua komponen pendidikan. Khusus di provinsi DKI Jakarta, keterlibatan pemerintah daerah masih terlihat cukup signifikan, terutama, dalam hal pembiayaan dan penyedian sarana prasarana. Hal ini memang agak berbeda dengan provinsi lain. PKBM di DKI Jakarta ini terbagi kepada dua kelompok, yaitu PKBM negeri yang jumlah tidak terlalu banyak dan PKBM swasta. Di provinsi-provinsi lain di Indonesia yang ada hanya swasta saja. Program-program yang dilakukan oleh PKBM sangat terkait langsung dengan kebutuhan masyarakat dan sekaligus membantu memecahkan sebagian permasalahan ibu kota. Dengan demikian, cukup beralasan jika keterlibatan pemerintah Provinsi DKI Jakarta terlihat cukup signifikan. Pelayanan yang diberikan oleh PKBM diharapkan dapat memberikan akses kepada masyarakat yang belum mendapatkan kesempatan layanan pendidikan atau masyarakat yang membutuhkan agar mampu beradaptasi dengan lingkungan dan perkembangan pembangunan di perkotaan.

Penelitian atau fokus kajian terhadap komitmen pengelola PKBM diperlukan, sehingga akan diperoleh informasi yang komprehensif tentang faktor-faktor yang secara empiris ikut mempengaruhi baik langsung atau tidak langsung terhadap komitmen organisasi para pengelola PKBM di DKI Jakarta. Hasil penelitian ini diharapkan dapat memberikan kontribusi terhadap pengambil kebijakan terutama pada PKBM yang urgensinya sangat strategis dalam upaya mencapai sumber daya manusia Indonesia yang unggul dan berkualitas, memiliki daya saing tinggi, di mana setiap warga masyarakat harus mampu beradaptasi dengan , perkembangan pembangunan khususnya di perkotaan Jakarta.

\section{Perumusan Masalah}

Berdasarkan latar belakang, maka dalam penelitian ini dapat dirumuskan beberapa permasalahar sebagai berikut.

1. Apakah gaya kepemimpinan berpengaruh langsung terhadap motivasi kerja pengelola PKBM? 
2. Apakah pengetahuan tentang prinsip dasar PLS berpengaruh langsung terhadap motivasi kerja pengelola $\mathrm{PKBM}$ ?

3. Apakah motivasi kerja berpengaruh langsung terhadap komitmen organisasi pengelola PKBM ?

4. Apakah gaya kepemimpinan berpengaruh tidak langsung terhadap komitmen organisasi melalui motivasi kerja pengelola PKBM ?

5. Apakah pengetahuan prinsip dasar PLS berpengaruh tidak langsung terhadap komitmen organisasi melalui motivasi kerja pengelola PKBM?

\section{KAJIAN TEORETIS}

\section{Kajian Teoretik}

Kajian yang lebih mendalam dan analisis yang enulikl lanldidadn-landasan teoritik yang memadai serta sudah teruji sebelumnya memerlukan suatu rujukan model teoritik. Model teoretik ini diperlukan untuk mengetahui seberapa jauh pengaruh gaya kepemimginan, pengetahuan prinsip dasar PLS, dan motivasi kerja terhadap komitmen organisasi. Rujukan model teoritik diharapkan dapat mendukung pengkajian dan penelitian yang dimaksud. Model teoretik yang dijadikan rujukan adalah sebagaimana terlihat pada desain di bewah ini:

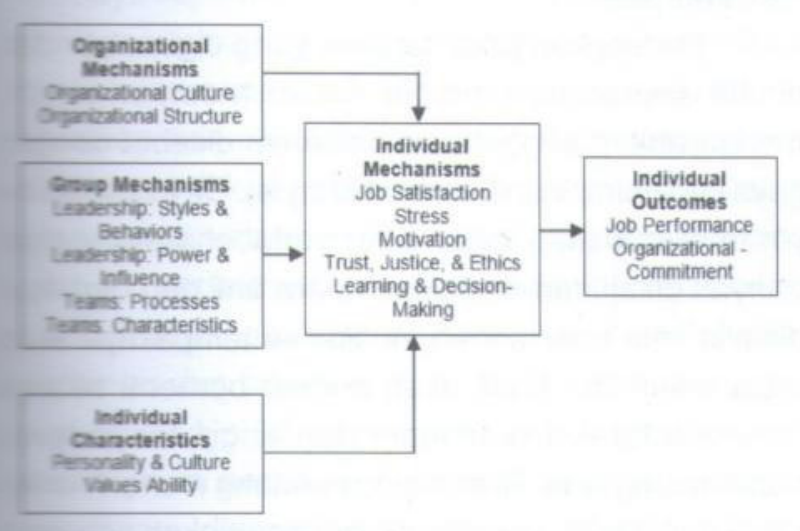

Gambar 1: Integrative Model of Organizational Behavior

Dari model integratif perilaku organisasi di atas, peneliti mengambil empat variabel secara teoretik Djadikan landasan utama dalam penelitian ini. Sambaran teoretik dari ke empat variabel tersebut atalah sebagai berikut;

\section{Komitmen Organisasi}

Salah satu pilar penting dalam pembangunan zenoidikan yang bermutu adalah adanya institusi, yang zalam pendidikan formal disebut dengan sekolah. Sekolah merupakan pusat pelayanan untuk nerperoleh pendidikan dan pelatihan. Sekolah pada jendidikan nonformal salah satunya dikenal dengan Psat Kegiatan Belajar Masyarakat (PKBM) yang seriomitmen untuk melakukan proses pembelajaran. Sebagai institusi pendidikan, PKBM harus menjadi sebuah organisasi pembelajaran. Sebagai organisasi pembelajaran fokusnya selalu sebagai tempat di mana peserta didik dapat secara terus - menerus memperluas kecakapannya untuk mencipta dan mencapai. PKBM juga sebagai tempat untuk mendorong pola pemikiran baru dan sebagai tempat menyalurkan aspirasi kolektif dipelajari, dan juga sebagai tempat belajar bersama.

Leithwood dan Louis (1998:33) mengatakan bahwa organisasi pembelajaran itu merupakan tempat di mana peserta didik mengejar tujuan bersama dengan komitmen kolektif untuk secara terus menerus mengevaluasi nilai tujuan, melakukan modifikasi agar sesuai, dan secara berkelanjutan mengembangkan cara-cara yang lebih efektif dan efisien mencapai tujuan. Untuk sampai pada tujuan sebagai sebuah organisasi pembelajaran, maka komitmen organisasi bagi seluruh komunitas PKBM merupakan sebuah keharusan, terutama bagi para pengelolanya, atau pemimpinnya.

Shaw, Delery \& Abdulla (2003: 2) memandang komitmen sebagai hasil investasi atau kontribusi terhadap organisasi, atau suatu pendekatan psikologis yang menggambarkan suatu hal yang positif, keterlibatan yang tinggi, orientasi intensitas tinggi terhadap organisasi.

Komitmen dalam ungkapan yang sama sebenarnya merupakan sikap yang merefleksikan loyalitas dan dedikasi pengikut pada organisasi dan proses berkelanjutan di mana para pengikut merefleksikan dan mengekspresikan perhatiannya terhadap organisasi serta keberhasilannya.

Mowdey, Porter \& Steers (1991: 328) memberikan batasan yang lebih luas, bahwa komitmen organisasi adalah kekuatan pegawai dalam mengidentifikasikan keterlibatan dirinya ke dalam bagian organisasi, yang dapat ditandai dengan penerimaan terhadap nilai-nilai dan tujuan organisasi, kesiapan dan kesediaan untuk berusaha dengan sungguh-sungguh atas nama organisasi, dan keinginan mempertahankan keanggotaan di dalam organisasi.

Dari pengertian, batasan dan definisi tersebut terlihat bahwa pada prinsipnya komitmen organisasi terkait dengan keterlibatan total seseorang dalam 
organisasi, baik secara kognitif maupun afektif.

Keterlibatan kognitif meliputi pandangan atau persepsi seseorang terhadap organisasi yang kemudian menuntun yang bersangkutan tertarik dan menerima nilai-nilai, tujuan, dan sasaran organisasi.

Keterlibatan afektif berwujud dalam bentuk keinginan dan kesediaan untuk berbuat yang terbaik demi organisasi, termasuk bertahan untuk tetap dalam organisasi. Ini berarti bahwa pimpinan maupun anggota harus ikut mendukung secara total dan menyeluruh atau juga dapat diperkirakan semakin tinggi keterlibatan seseorang pada suatu perkembangan organisasi, akan semakin tinggi juga komitmen dan semakin tinggi juga produktivitas yang dicapai.

Alien dan Meyer (Luthans: 2006, 147) membagi komitmen organisasi kedalam tiga dimensi yaitu;

a) komitmen afektif (affective commitment) yaitu involves the employee's emotional attachment to identification with, is involvement in the organization (keterikatan emosi karyawan/anggota, identifikasi dengan organisasinya, dan keterlibatan anggota terhadap kegiatan organisasi),

b) komitmen berkelanjutan (continuence commitment) yaitu involves commitment based on the cost that the employee associated with leaving the organization (komitmen berdasarkan kesadaran anggota terhadap organisasinya akan mengalami kerugian apabila meninggalkan organisasi),

c) komitmen normatif (normative commitment) yaitu involves employee's feeling of obligation to stay with the organization (menggambarkan perasaan keterikatan untuk terus berada dalam organisasi. perasaan wajib tetap berada dalam organisasi karena memang harus begitu, tindakan itu adalah hal yang benar yang harus dilakukan).

Bertitik tolak dari beberapa teori di atas, maka dapat disintesiskan bahwa komitmen organisasi para pengelola PKBM itu adalah sikap yang merefleksikan loyalitas pengelola pada PKBM dan proses berkelanjutan di mana para pengelola mampu mengekpresikan perhatiannya terhadap organisasi dan keberhasilan serta kemajuan yang berkelanjutan, dengan dimensi (1) kontinyu dan aktif berpartisipasi, (2) menjalankan norma-norma organisasi, (3) keinginan berusaha untuk organisasi, dan (4) hasrat tetap menjadi anggota organisasi.

\section{b. Gaya Kepemimpinan}

Robbin and Timothy (2007: 49) mengemukakan bahwa kepemimpinan adalah kemampuan untuk mempengaruhi suatu kelompok guna mencapai sebuah visi atau serangkaian tujuan yang ditetapkan. Kepemimpinan adalah kemampuan seseorang untuk mempengaruhi, memotivasi orang lain untuk dapa memberikan kontribusi menuju tercapainya efektiv dan kesuksesan oraganisasi. Dari pengertian-pengertian tersebut terlihat bahwa kata kunci dari kepem pinan tersebut adalah "mempengaruhi". Sumber pengz ruh ini bisa saja datang dari kepercayaan organisa yang lebih bersifat formal, seperti yang diber pemangku jabatan manajerial dalam sebuah orgar atau bisa juga dari yang lainnya.

Beberapa pandangan menjelaskan báhwa kes mimpinan itu pada dasarnya adalah seni menggera kan, mempengaruhi, atau membimbing dan mengara kan orang lain dalam rangka mencapai tujuan org sasi. Ada empat unsur yang terkandung dalam pengt tian kepemimpinan di atas, yaitu (1) unsur orang, menggerakkan dan mempengaruhi yang dikedengan nama pemimpin (leader), (2) unsur orang digerakkan atau dipengaruhi yang dikenal deng sebutan kelompok atau anggota (followers), (3) situasi di mana aktivitas pergerakkan berlangsung dikenal dengan nama organisasi (organization), dan unsur tujuan, yakni ke arah mana organiasi terse harus berjalan.

Sedangkan pola perilaku yang digunakan dipilih seorang pemimpin dalam mempengar mengarahkan anggotanya biasanya disebut den gaya kepemimpinan (leadership style). Gaya kepern pinan merupakan salah satu variabel yang san banyak dikaji dan diteliti oleh para ahli dari berbas disiplin ilmu belakangan ini. Hal ini tampaknya terus dikaji dan tidak akan pernah berhenti se proses interaksi pemimpin dan anqqotanya berlangsung juga. Di samping memang menarik dikaji dan diteliti, variabel ini mencerminkan apa dilakukan dan diperbuat oleh pemimpin (pola peri atau pilihan-pilihan perilaku pemimpin dalam me pengaruhi pengikut atau mitra kerjanya merealisasikan visi, misi, dan tujuan organisasi sudah dirumuskan atau ditetapkan. Pola perilaku dimaksudkan adalah pola perilaku yang dinamis, cara-cara atau strategi yang dipilih dan digunakan o setiap pemimpin dengan selalu mempertimban dengan siapa dan pada tingkat komatangan bagaimana dimiliki oleh para pengikutnya.

Kemudian dikemukakan lagi bahwa kepemimpinan merupakan fungsi dari kompone komponen yang terdiri dari pemimpin itu sent bawahan, dan situasi. Gaya kepemimpinan dapa diartikan sebagai cara seorang pemimpin melaks kan kegiatannya dalam upaya membimbing, mema mengarahkan, dan mengontrol pikiran, perasaan, perilaku seseorang atau sejumlah orang untuk mer 
tujuan tertentu.

Menurut Davis dan Newstorm (1998: 205) bahwa "leadership style is the total pattern of leader's action, as perceived by their employees." Definisi ini lebih menitikberatkan gaya kepemimpinan yang berhubungan langsung dengan pilihan perilaku pemimpin, bagaimana mempengaruhi, menggerakkan, dan mengarahkan mitra kerjanya. Dalam Path-goal Theory, House sebagaimana dikutip oleh Newstorm dan Davis (1989: 333) terdapat empat gaya kepemimpinan yaitu (1) kepemimpinan uirekur (ưrecrive reađership), (2) kepemimpinan suportif (supportive leadership), (3) kepemimpinan partisipatif (participative leadership), dan (4) kepemimpinan yang berorientasi pada prestasi (achvievement oriented leadership).

Gaya kepemimpinan autoritative-eksploitatif mencirikan perilaku diktator pemimpin, di mana semua jenis dan bentuk keputusan dibuat hanya oleh pimpinan. Kalaupun ada keterlibatan para bawahan jumlahnya hanya sedikit. Di sisi lain, perilaku saling tidak percaya di antara masing-masing anggota kelompok merupakan ciri lainnya yang terdapat pada gaya kepemimpinan ini. Gaya kepemimpinan yang authoritative benevolent menggambarkan perilaku pimpinan yang masih otoriter namun berusaha untuk secara bijak memotivasi para bawahan dalam aktivitas kerja demi tercapainya tujuan organisasi. Sikap saling mencurigai antara pimpinan dan bawahan masih terlihat dalam gaya kepemimpinan jenis ini. Berikutnya, gaya kepemimpinan konsultatif, mencirikan sikap saling memperhatikan, peduli di antara pimpinan dan para anggota, serta sesama anggota organisasi. Hal ini dikarenakan pimpinan senantiasa merangkum berbagai masukan dari para anggota organisasi, dengan tetap mempertahankan haknya untuk membuat keputusan akhir. Gaya kepemimpinan partisipatif menggambarkan sikap para anggota organisasi yang sangat aktif terlibat dalam berbagai kegiatan organisasi.

Gaya kepemimpinan yang pada umumnya dipakai adalah gaya kepemimpinan yang berorientasi pada keseimbangan paduan/integrasi dimensi tugas, dimensi manusia. Gaya ini disebut shared leadership style (gaya kepemimpinan terpadu) dan cenderung bersifat demokratis. Gaya kepemimpinan jenis ini lebih menghasilkan moralitas dan produktivitas yang tinggi (Luthans : 206, 214).

Dari beberapa pendapat para ahli tentang gaya kepemimpinan di atas, maka dapat disintesiskan bahwa pada dasarnya gaya kepemimpinan tersebut berintikan pola perilaku setiap pemimpin dalam mempengaruhi, menggerakan, mengarahkan para pengikut atau mitra kerjanya dalam upaya mencapai tujuan organisasi yang dipimpinnya. Gaya tersebut memiliki dimensi-dimensi sebagai berikut: (1) berorientasi kepada tugas, yaitu lebih menekankan pada aspek-aspek teknis atau tugas dari pekerjaan tertentu; dan (2) berorientasi pada orang atau anggota yaitu menekankan kepada hubungan antarpersonal, mementingkan kebutuhan anggota dan menerima perbedaan individual di antara para anggota. Kedua dimensi ini akan menjadi acuan dalam mengembangkan indikator-indikator untuk instrumen penelitian.

\section{c. Pengetahuan tentang Prínsip Dasar P̄LS}

Sementara Robbins and Timothy (2007: 42) memberikan rumusan bahwa kemampuan kognitif itu adalah kapasitas seseorang untuk menunjukkan prestasi pada beberapa tugas dalam sebuah pekerjaan. Dalam kerangka pengertian di atas, Aderson dan Krathwohl (2001: 27) membagi pengetahuan kepada empat dimensi, yaitu (1) faktual, (2) konseptual, (3) prosedural, (4) metakognitif. Colquitt,dkk (2009: 340) memberikan pandangan dalam pengetahuan seperti yang sudah diungkapkan di atas dengan istilah Cognitive Ability (kemampuan kognitif) dan ini sama halnya dengan pengetahuan yang dimaksudkan dalam variabel di atas. Colquitt membagi cognitive ability menjadi lima kategori atau bentuk, yaitu (1) verbal ability, (2) Quantitative ability, (3) reasoning ability, (4) spatial ability, dan (5) perceptual ability.

Berdasarkan beberapa pandangan di atas dapat disimpulkan bahwa pengetahuan itu adalah semua informasi yang tersimpan dalam ingatan seseorang yang memungkinkan dirinya dapat menggunakan informasi tersebut untuk menunjang kehidupan yang meliputi faktual, konseptual, prosedural, dan metakognitif.

Pendidikan Nonformal (PNF) diarahkan untuk memberikan layanan pendidikan kepada warga masyarakat yang belum memperoleh pendidikan, tidak pernah sekolah atau buta aksara, putus sekolah, dan warga masyarakat lainnya yang kebutuhan pendidikannya tidak dapat terpenuhi melalui jalur pendidikan formal. Sasaran Pendidikan Nonformal (PNF) mencakup segala lapisan masyarakat, tidak terbatas pada usia, jenis kelamin, status sosial ekonomi, dan tingkat pendidikan sebelumnya. Sasaran tersebut tidak hanya diprioritaskan kepada yang belum pernah sekolah, putus sekolah, atau yang tamat sekolah serta ingin mendapat pekerjaan, PNF juga melayani semua masyarakat tanpa kecuali, termasuk yang telah memiliki tingkat pendidikan tinggi dan pekerjaan tetap. Dengan demikian, Pendidikan Nonformal bertujuan untuk memberikan layanan pendidikan kepada semua warga masyarakat, agar memiliki kemampuan untuk mengembangkan potensi diri dengan penekanan pada 
penguasaan pengetahuan dan keterampilan vokasional, serta pengembangan sikap dan kepribadian profesional, sehingga Pendidikan Nonformal dapat pula berfungsi sebagai pengganti, penambah, dan/atau pelengkap pendidikan formal dalam mendukung pendidikan sepanjang hayat.

Ada beberapa ciri Pendidikan Nonformal yang dapat diketahui, sebagai berikut (1) dapat dilaksanakan secara fleksibel, tidak terikat waktu, tempat, dan usia peserta didik; (2) dilaksanakan atas dasar prinsip dari, oleh, dan untuk masyarakat; (3) eligibilitas sebagai pengganti, penambah, dan pelengkap pendidikan formal; (4) layanan program relevan dan sesuai dengan kebutuhan serta potensi masyarakat setempat; dan (5) mengutamakan pelayanan terhadap masyarakat yang belum terakses pendidikan atau masyarakat marginal.

Untuk memberikan layanan pendidikan yang optimal terhadap masyarakat melalui jalur penyelenggaraan pendidikan nonformal, dibutuhkan pendidik dan tenaga kependidikan Pendidikan Nonformal (PTK-PNF) yang handal dan profesional. Profesionalisme PTK-PNF dalam pelaksanaan tugas pokok dan fungsinya merupakan tuntutan yang harus dimiliki dalam memberikan layanan pendidikan nonformal kepada masyarakat terutama yang membutuhkannya. Oleh karena itu, PTKPNF harus diberdayakan dalam pemberian layanan kepada masyarakat melalui penyelenggaraan Pendidikan Nonformal yang berkualitas.

Prinsip-prinsip dasar Pendidikan Nonformal atau sering juga disebut dengan pendidikan berbasis masyarakat seperti yang diungkapkan oleh Galbraith yang dikutip Sudjana (2004: 48):

1) Self determination.

2) Self help.

3) Leadership development.

4) Localization.

5) Integrated delivery of service.

6) Accept diversity.

7) Reduce duplication.

8) Institutional responsiveness.

9) Life long learning.

Dari beberapa pengertian dan pembahasan di atas dapat disintesiskan bahwa pengetahuan tentang prinsip dasar PLS (PNF) itu adalah semua informasi yang berkaitan dengan konsep dasar pendidikan di luar sistem persekolahan atau pendidikan nonformal dengan dimensi (1) karakteristik peserta didik PLS(PNF), (2) karakteristik tenaga pedidik dan tenaga kependidikan PLS(PNF), (3) karakteristik program PLS (PNF), dan (4) karakteristik pengelolaan satuan PLS (PNF).

\section{d. Motivasi Kerja}

Robinns dan Timothy (2007: 166) memberikan batasan bahwa motivasi adalah proses yang menjelaskan seorang individu tentang intensitas, arah, dan kegigihan berusaha untuk mencapai suatu tujuan. Intensitas berkenaan dengan bagaimana seseorang berusaha keras. Petunjuk atau arah berkenaan dengan kualitas usaha dan konsistensi sedangkan kegigihan berkenaan dengan ukuran seberapa lama seseorang dapat menjaga usahanya. Dengan demikian, dapat juga dikatakan bahwa motivasi merupakan proses psikologis, di mana terjadi interaksi antara sikap, kebutuhan, persepsi, proses belajar, dan problem solving.

Ada dua jenis teori motivasi yang secara umum banyak dikaji dan ditelaah terutama dalam perilaku organisasi:

a) Content Theories yang berfokus kepada "apa", mengidentifikasi faktor-faktor yang menyebabkan individu melakukan usaha daiam kerja. Dengan demikian, pendekatan ini berusaha mengidentifikasi kebutuhan seseorang yang relatif kuat dan tujuan yang dikejar untuk memenuhi kebutuhan tersebut.

b) Process Theories yang berfokus kepada "bagaimana" langkah-langkah individu menempatkan usaha. Dengan demikian, pendekatan ini berupaya mengidentifikasi hubungan antara faktor-faktor yang membentuk motivasi. Pendekatan ini juga menjelaskan bagaimana motivasi diaktifkan, sehingga cenderung dapat menjelaskan pilihan, keteguhan usaha yang berarti, fokusnya pada bagaimana perilaku dimulai, diarahkan, dan dipelihara atau dipertahankan.

Motivasi kerja, sebenarnya dapat dibedakan menjadi tiga kelompok besar yakni yang berlandaskan pada kebutuhan, kesadaran, dan pemberian dukungan atau yang sering juga dikenal dengan sebutan penguatan (reinforcement).

Motivasi kerja menurut Baron \& Greenberg (1990: 88) dalam teorinya "Expectancy Theory" adalah hasil dari tiga keyakinan yang dimiliki setiap orang yang meliputi (a) expectancy, percaya bahwa setiap usaha akan membuahkan hasil atau prestasi; (b) instrumentally, percaya bahwa setiap prestasi akan dihargai atau mendapat imbalan; dan (c) valence, penghargaan atau imbalan bernilai bagi penerima.

Berdasarkan beberapa definisi dan pembahasan di atas, maka dapat disintesiskan bahwa motivasi kerja pengelola PKBM adalah kondisi-kondisi di dalam dan di luar individu pengelola PKBM yang menyebabkan adanya keragaman dalam intensitas, kualitas, arah, dan lamanya perilaku kerja dalam organisasi, dengan dimensi (1) penilaian terhadap pekerjaan, (2) berprakarsa dalam melaksanakan pekerjaan, serta (3) 
bertanggung jawab pada tugas yang dibebankan.

\section{Kerangka Berpikir}

a) Gaya kepemimpinan berpengaruh langsung terhadap motivasi kerja Pengelola PKBM

sedagaımana dıketahui bahwa gaya kepemimpi-

nan adalah pola perilaku pemimpin dalam mempengaruhi mitra kerja atau bawahan dalam upaya mencapai tujuan organisasi. Mempengaruhi mitra kerja atau bawahan merupakan cara, teknik, dan kiat yang dapat mempengaruhi mitra kerja dalam menjalankan suatu tugas yang harus diemban sesuai dengan tugas pokok dan fungsi masing-masing, sehingga tujuan organisasi tercapai. Di saat mitra kerja atau bawahan dapat melakukan tugas pokok dan fungsinya secara terus menerus sebagaimana mestinya, maka hal ini dapat diasumsikan bahwa proses melakukan tugas pokok tersebut dan hasil kerja sesuai dengan tujuan merupakan indikasi motivasi kerja tinggi atau dalam kalimat lain diperkirakan/diduga bahwa ada pengaruh langsung gaya kepemimpinan yang dimiliki seseorang terhadap motivasi kerja pengelola PKBM.

b) Pengetahuan prinsip dasar PLS berpengaruh langsung terhadap motivasi kerja pengelola PKBM

Semua program yang direncanakan dan dilaksanakan oleh PKBM sangat terkait dengan tingkat kebutuhan kelompok sasaran yang memang sangat berbeda apabila dikomparasikan dengan kelompok sasaran pendidikan formal (persekolahan) yang kebutuhan kelompok sasaranya hampir sama, sehingga kurikulumnya dibuat sama untuk semua tingkat dan jenjang. Berbeda halnya dengan kelompok sasaran Pendidikan Nonformal, di mana materi dan kurikulummya harus disesuaikan dengan kebutuhan pesertanya atau siapa yang membutuhkannya, dan hal ini merupakan salah satu karakteristik Pendidikan Nonformal itu sendiri.

Keberhasilan semua program ini sangat banyak citentukan oleh tingkat kemampuan pengelola (jemimpin PKBM) dalam memahami karakteristik yang dimiliki oleh kelompok sasaran Pendidikan Nonformal ini, termasuk memahami atau pengetahuan aspekaspek lain dari pendidikan nonformal. Oleh karena itu, pemathaman dan penguasaan tentang prinsip dasar PLS.(pendidikan nonformal) oleh seorang pemimpin dalam hal pemimpin PKBM merupakan keharusan. Karena dengan pemahaman dan penguasaan terhadap grinsip dasar PLS tersebut, diasumsikan bahwa genahaman dan penguasan pengelola PKBM terhadap grinsip dasar Pendidikan Luar Sekolah (Pendidikan Nonformal) akan sangat berpengaruh terhadap motivasi kinerja pengelola PKBM itu sendiri secara langsung.

c) Gaya kepemimpinan berpengaruh langsung terhadap komitmen organisasi pengelola PKBM

Seperti yang sudah diutarakan di atas bahwa gaya kepemimpinan seseorang terhadap sebuah institusi, dalam hal ini PKBM, merupakan pola perilaku seorang pemimpin dalam upaya mempengaruhui mitra kerja atau bawahan untuk mencapai tujuan organisasi. Mempengaruhi bawahan atau mitra kerja merupakan proses interaksi antara pemimpin dengan bawahan yang tidak hanya terjadi proses komunikasi satu arah saja, akan tetapi di dalamnya berhimpun berbagai unsur yang tidak dapat dipisahkan antara satu dengan yang lainnya. Sebagai contoh, proses komunikasi yang berlangsung antara pimpinan dan bawahan melibatkan emosi, perilaku, tata krama dan lainnya, yang ke semua itu sangat berhubungan dengan efektif tidaknya komunikasi itu dilaksanakan dan tentu hal ini akan menentukan tinggi rendahnya komitmen seseorang untuk tetap melakukan sesuatu dan bekerja secara tetap dalam suatu lembaga. Sekaligus juga akan berpengaruh terhadap hasil kerja. Oleh karena itu, diasumsikan bahwa gaya kepemimpinan berpengaruh langsung terhadap komitmen organisasi pengelola PKBM.

d) Pengetahuan prinsip dasar PLS berpengaruh langsung terhadap komitmen organisasi pengelola PKBM.

Sama halnya dengan pernyataan di atas bahwa semua program yang direncanakan dan dilaksanakan oleh PKBM sangat terkait dengan tingkat kebutuhan kelompok sasaran yang memang sangat berbeda apabila dikomparasikan dengan kelompok sasaran pendidikan formal (persekolahan) yang kebutuhan kelompok sasarannya sama, sehingga kurikulumnya dibuat sama untuk semua sesuai dengan jenjang. Berbeda dengan kelompok sasarannya, materi dan kurikulum Pendidikan Nonformal, harus disesuaikan dengan kebutuhan pesertanya.

Di sinilah perlunya seorang pengelola/pemimpin PKBM untuk memahami dan menguasai prinsip dasar Pendidikan Nonformal (pendidikan luar sekolah), yang meliputi konsep, prosedur, teori, dan lain-lain, sehingga dengan memiliki kemampuan kognitif tentang prinsip dasar PLS tersebut diasumsikan akan berpengaruh terhadap motivasi kerja, karena hambatan apapun yang akan ditemui dalam proses pengelolaan sudah dapat diantisipasi. Jadi, keinginan yang kuat untuk melakukan proses secara terus menerus tidak menjadi terhalang/ terkendala, dan tidak ada kata menyerah atau pendek kata, dorongan untuk melakukan proses pengelolaan terhada PKBM tidak pernah surut dan berhenti. Oleh karena itu, diasumsikan bahwa kemampuan kognitif pengelola PKBM tentang prinsip dasar Pendidikan 
Pengaruh Gaya Kepemimpinan, Pengetahuan...

Nonformal akan berpengaruh langsung terhadap komitmen organisasi para pengelola PKBM.

e) Motivasi kerja berpengaruh langsung terhadap komitmen organisasi pengelola PKBM

Seperti juga yang sudah diungkapkan di atas bahwa motivasi kerja merupakan dorongan psikologis untuk melakukan suatu pekerjaan yang indikator terlihat pada kebutuhan eksistensi (keberadaannya dalam organisasi), kebutuhan terhadap hubungan (komunikasi dengan pihak lain) dan kebutuhan perkembangan yang mengarah kepada suatu kemajuan secara terus menerus. Di saat seorang pemimpin PKBM sudah mampu melakukan aktivitas dan melihat hasil kerja keras sesuai dengan harapan atau tujuan organisasi, maka disitu juga terlihat bahwa seseorang akan konsisten melakukan sesuatu. Kekonsistenan tersebut, disebabkan oleh berbagai faktor pendorong untuk melakukan suatu tugas organisasi, terutama tugastugas spesifik dalam oranisasi yang dipimpin. Kalau hal ini terus berjalan maka diasumsikan bahwa motivasi kerja berpengaruh langsung terhadap komitmen organisasi para pengelola PKBM.

\section{Hipotesis Penelitian}

Berdasarkan kajian teoretis dan kerangka berpikir seperti yang diutarakan di atas, maka hipotesis dalam model kausalitas yang dapat diuji melalui penelitian ini adalah:

1) Terdapat pengaruh langsung gaya kepemimpinan terhadap motivasi kerja pengelola PKBM di Wilayah DKI Jakarta.
2) Terdapat pengaruh langsung pengetahuan prinsip dasar PLS terhadap motivasi kerja pengelola PKBM. di Wilayah DKI Jakarta.

3) Terdapat pengaruh langsung gaya kepemimpinan terhadap komitmen organisasi pengelola PKBM. di Wilayah DKI Jakarta.

4) Terdapat pengaruh langsung pengetahuan prinsip dasar PLS terhadap komitmen organisasi pengelola PKBM di Wilayah DKI Jakarta.

5) Terdapat pengaruh langsung motivasi kerja terhadap komitmen organisasi pengelola PKBM. di Wilayah DKI Jakarta.

Model hipotetik dari penelitian ini dapat digambarkan sebagai berikut.

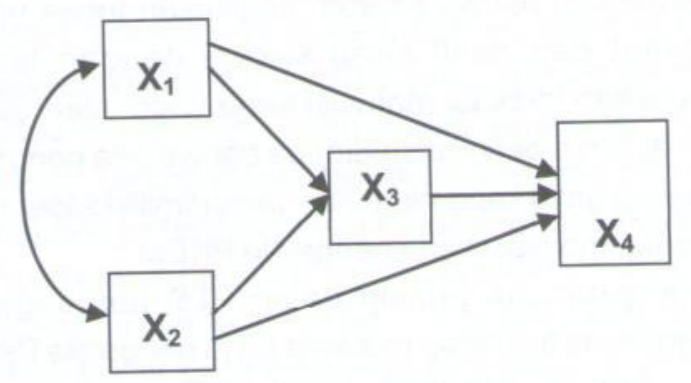

Keterangan:

$X_{1}=$ Gaya Kepemimpinan

$\mathrm{X}_{2}=$ Pengetahuan Prinsip Dasar PLS

$\mathrm{X}_{3}=$ Motivasi Kerja

$\mathrm{X}_{4}=$ Komitmen Organisasi

\section{METODOLOGI PENELITIAN}

Penelitian ini bertujuan untuk mengetahui apakah terdapat pengaruh dan seberapa besar pengaruhnya.

1) Gaya kepemimpinan terhadap motivasi kerja pengelola PKBM di Wilayah DKI Jakarta.

2) Pengetahuan prinsip dasar PLS terhadap motivasi kerja pengelola PKBM di Wilayah DKI Jakarta.

3) Gaya kepemimpinan terhadap komitmen organisasi pengelola PKBM di Wilayah DKI Jakarta.

4) Pengetahuan prinsip dasar PLS terhadap komitmen organisasi pengelola PKBM di Wilayah DKI Jakarta.

5) Motivasi kerja terhadap komitmen organisasi pengelola PKBM di Wilayah DKI Jakarta.

Penelitian ini dilaksanakan di wilayah provinsi DKI Jakarta dalam waktu 5 bulan, dari Maret sampai Agustus 2009.

Metode yang digunakan dalam penelitian ini adalah metode survey dengan teknik analisis jalur (path analysis).
Populasi target pada penelitian ini adalah seluruh pengelola PKBM yang terdaftar dan berproses aktif dalam penyelenggaraan program PLS atau Pendidikan Nonformal di wilayah Provinsi DKI Jakarta. Adapun populasi terjangkau yang menjadi target penelitian adalah pengelola PKBM yang terdaftar dan berproses aktif dalam penyelenggaraan program PLS atau Pendidikan Nonformal di wilayah propinsi DKI Jakarta sejumlah 170 PKBM, 170 PKBM negeri dan PKBM swadaya. Hal ini berarti pengelola atau pemimpin PKBM berjumlah 170 orang.

Sampel dalam penelitialı inli vianuil Uonyan menggunakan teknik Cluster Random Sampling dengan rincian untuk PKBM Swadaya maka pengambilan sampel dilakukan dengan perhitungan $50 \% \times 140=70$. Kemudian untuk PKBM Negeri maka pengambilan sampel dilakukan dengan perhitungan $50 \% \times 30=15$. Dengan demikian, diperoleh ukuran 
sampel sebanyak 85 pengelola $\mathrm{PKBM}$ dengan rincian 70 Pengelola PKBM swadaya dan selebihnya 15 pengelola PKBM negeri yang dianggap bisa mewakili semua pengelola yang terdaftar dan berproses aktif dalam penyelenggaraan program PLS atau pendidikan nonformal di DKI Jakarta.

Pengumpulan data untuk setiap variabel menggunakan instrumen yang dikembangkan oleh nanoliti dan disotujui oleh Promotor. Penyusunan instrumen didasarkan pada indikator-indikator untuk tiap variabel dari teori-teori yang telah dibangun, selanjutnya tiap indikator dijabarkan kedalam butir-butir pernyataan.

Variabel $x_{1}$, variabel $x_{3}$ dan variabel $x_{4}$ menggunakan kuesioner dengan skala penilaian (1) selalu, (2) sering, (3) kadang-kadang, (4) jarang dan (5) tidak pernah, sedang variabel $X_{2}$ menggunakan bentuk asesmen tes dengan pilihan ganda. Instrumen yang disusun diuji validitas dan realibilitasnya. Hal ini dilakukan dengan tujuan menjamin kualitas instrumen dan memenuhi persyaratan ilmiah sehingga dapat digunakan sebagai sarana atau alat pengumpul data dalam penelitian ini.

Dari penghitungan uji validitas butir komitmen organisasi dengan menggunakan rumus korelasi Pearson's product moment, menghasilkan butir-butir yang valid 27 . Sedangkan berdasarkan penghitungan reliabilitas dengan menggunakan rumus $A / p h a$ Cronvbach, instrumen komitmen organisasi diperoleh nilai 0,976 . Pada variabel gaya kepemimpinan diperoleh butir valid sebanyak 27 dengan reliabilitas 0,933 , variabel Pengetahuan prinsip dasar PLS diperoleh butir valid sebanyak 32 dan perhitungan realibilitas dengan rumus KR-20 diperoleh angka 0,892, dan variabel motivasi kerja diperoleh butir valid sebanyak 30 dengan angka realibilitas 0,959.

Analisis data menggunakan teknik analisis deskriptif bertujuan memberikan gambaran data masingmasing variabel, yang disajikan dalam bentuk: nilai ratarata, median, modus, simpangan baku, varians, dan distribusi frekuensi yang disertai dengan grafik dalam bentuk histogram. Sebelum dilakukan proses pengujian hipotesis maka perlu dilakukan uji prasyarat analisis yang terdiri dari uji normalitas dan uji homogenitas data antar variabel. Uji normalitas dilakukan untuk menentukan apakah data dari lapangan tersebut berdistribusi normal atau tidak, dan diuji dengan menggunakan uji normalitas chi kuadrat dari Lilliefors, sedangkan uji homogenitas dilakukan untuk menentukan apakah data tersebut homogen. Uji ini menggunakan uji homogenitas dari Baritlett. Untuk menghitung pengaruh langsung dan tidak langsung dari variabel bebas terhadap variabel terikat, tercermin dari koefisien jalur. Sedangkan untuk menentukan koefissien jalur memerlukan persyaratan antara lain; (1) hubungan antara tiap dua variabel bebas harus merupakan hubungan linear, aditif, dan kausal, (2) sistem menganut satu arah, (3) semua variabel residu tidak saling berkorelasi dengan variable penyebab, dan (4) data masing-masing adalah kontinum.

Dalam model analisis jalur dikenal dua tipe variabel, yakni variabel eksogen dan variabel endogen. Variabel eksogen memberikan pengaruh, baik langsung maupun tidak langsung terhadap variabel endogen. Perhitungan dilakukan dengan alat bantu komputer. Program yang digunakan adalah paket data analisis yang terdapat dalam Microsoft, excel dan SPSS.

\section{HASIL PENELITIAN}

Deskripsi data variabel gaya kepemimpinan $\left(X_{1}\right)$, pengetahuan prinsip dasar $\operatorname{PLS}\left(\mathrm{X}_{2}\right)$, motivasi kerja $\left(\mathrm{X}_{3}\right)$, dan komitmen organisasi $\left(X_{4}\right)$ disajikan dalam tabel berikut.

-Tabel 1 : Rangkuman data hasil penelitian

\begin{tabular}{|c|c|c|c|c|}
\hline & $\mathbf{X}_{1}$ & $\mathbf{X}_{2}$ & $\mathbf{X}_{3}$ & $\mathbf{X}_{4}$ \\
\hline$n$ & 85 & 85 & 85 & 85 \\
\hline Rata-rata & 107,38 & $\begin{array}{c}22.7 \\
4\end{array}$ & $\begin{array}{c}114.9 \\
6\end{array}$ & $\begin{array}{c}111 . \\
69\end{array}$ \\
\hline Median & 106 & 23 & 116 & 111 \\
\hline Modus & 102 & 23 & 112 & 112 \\
\hline Std. Dev. & 8.56 & 8.06 & 9.57 & 8.90 \\
\hline Minimal & 90 & 11 & 82 & 92 \\
\hline Maksimal & 126 & 32 & 131 & 130 \\
\hline
\end{tabular}

\section{Pengujian Persyaratan Analisis}

Sesuai dengan kaidah ilmiah dalam pengujian statistik parametrik, maka sebelum data dihitung untuk keperluan pengujian hipotesis, terlebih dahulu harus dipenuhi beberapa persyaratan analisis. Sekurangkurang ada empat persyaratan analisis yang harus dipenuhi, yaitu data harus berdistribusi normal, kelompok data harus memiliki varians yang homogen, tidak terjadi multikolinearitas dan regresi bentuk linear.

Analisis jalur (path analysis) mempersyaratkan data yang akan dianalisis memenuhi beberapa bentuk uji statistik. Oleh karena itu, sebelum dilakukan pengujian hipotesis terlebih harus dilakukan uji persyaratan seperti; (1) uji normalitas, (2) uji homogenitas, (3) uji signifikansi, dan linearitas koefisien regresi. 


\section{a. Uji Normalitas}

Uji normalitas dilakukan untuk menguji apakah sebaran dari skor masing-masing variabel berdistribusi normal, mendekati normal atau tidak normal. Uji normalitas data dilakukan dengan uji Liliefors yang berdistribusi Chi-Square, terhadap empat kelompok data sesuai variabelnya. Rangkuman hasil perhitungan uji normalitas data dapat dilihat pada tabel berikut.

Tabel 2 : Rangkuman Analisis Uji Normalitas Data

\begin{tabular}{||c|c|c|c|c|c||}
\hline No & Var. & $n$ & $L_{0}$ & $L_{t}$ & Ket. \\
\hline 1 & $X_{1}$ & 85 & 0.088 & 0.961 & Normal \\
\hline 2 & $X_{2}$ & 85 & 0.090 & 0.961 & Normal \\
\hline 3 & $X_{3}$ & 85 & 0.092 & 0.961 & Normal \\
\hline 4 & $X_{4}$ & 85 & 0.086 & 0.961 & Normal \\
\hline
\end{tabular}

Keterangan:

$\mathrm{X}_{1}=$ Gaya Kepemimpinan

$\mathrm{X}_{2}=$ Pengetahuan Prinsip Dasar PLS

$\mathrm{X}_{3}=$ Motivasi Kerja

$\mathrm{X}_{4}=$ Komitmen Organisasi

\section{b. Uji Homogenitas}

Uji Bartlett untuk varians skor data gaya kepemimpinan $\left(X_{1}\right)$, pemahaman dasar prinsip $\operatorname{PLS}\left(X_{2}\right)$, motivasi kerja $\left(X_{3}\right)$ dan komitmen organisasi $\left(X_{4}\right)$ diperoleh nilai $\div{ }^{2}$ hitung $<\div^{2}$ tabel pada taraf á $=0.05$, yaitu $3.9754<7.81$. Persyaratan varians homogen adalah jika $\div{ }^{2}$ hifung $<\div^{2}$ tabel. Karena $\div^{2}$ hitung $3.9754<\div 2$ tabel 7.81, maka variansi gaya kepemimpinan $\left(X_{1}\right)$, pemahaman dasar prinsip PLS $\left(X_{2}\right)$, motivasi kerja $\left(X_{3}\right)$ dan komitmen organisasi $\left(X_{4}\right)$ berasal dari populasi yang homogen. Dengan demikian, variansi variabel gaya kepemimpinan $\left(X_{1}\right)$, pemahaman dasar prinsip $\operatorname{PLS}\left(X_{2}\right)$, motivasi kerja $\left(X_{3}\right)$ dan komitmen organisasi $\left(X_{4}\right)$ adalah homogen.

Hasil Uji Bartlett di atas, maka rangkuman hasil uji Bartlett untuk varians adalah sebagai berikut.

Tabel 3. Rangkuman Uji Bartlett

\begin{tabular}{|c|c|c|c|c|}
\hline Variabel & $\mathrm{dk}$ & $\chi^{2}{ }_{\text {hit }}$ & $\begin{array}{c}\chi_{\text {tabel }}^{2} \\
(\mathrm{a}=0.05)\end{array}$ & Ket. \\
\hline $\mathrm{X}_{1}, \mathrm{X}_{2}, \mathrm{X}_{3}, \mathrm{X}_{4}$ & 3 & 2.636 & 7.81 & Homogen \\
\hline \multicolumn{3}{|c|}{ Syarat homogenitas $\mathrm{X}_{\text {hitung }}^{2}<\mathrm{X}_{\text {tabel }}^{2}$} \\
\hline
\end{tabular}

Uji Signifikansi dan Linearitas Koefisien Regresi.

Uji signifikasi pada penelitian ini menggunakan dua regresi yaitu regresi gaya kepemimpinan dan pemahaman prinsip dasar PLS terhadap motivasi kerja dan motivasi kerja terhadap komitmen organisasi

1) Gaya Kepemimpinan dan Pemahaman Prinsip Dasar PLS terhadap Motivasi Kerja.

Dari hasil perhitungan Analisis Regresi di dapat Tabel Anava sebagai berikut :

Tabel 4. Analisis variansi regresi $\mathrm{X}_{3}$ atas $\dot{\mathrm{X}}_{1}$ dan $\mathrm{X}_{2}$

\begin{tabular}{|c|c|c|c|c|c|}
\hline $\begin{array}{c}\text { Sumber } \\
\text { Variasi }\end{array}$ & $d k$ & JK & RJK & $F_{\text {hit }}$ & $F_{\text {tab. }}$ \\
\hline Regresi & 2 & 6606,99 & 3303,49 & 88,74 & 3,11 \\
\hline Sisa & 82 & 3052,60 & 37,227 & & \\
\hline Total & 84 & 9659,60 & & & \\
\hline
\end{tabular}

Dari hasil perhitungan di atas diperoleh harga $F_{\text {hitung }}$ sebesar 88.740 sedangkan $F_{\text {tabel }}$ dengan $\mathrm{dk}$ pembilang 2 dan penyebut 82 pada taraf signifikansi $a=0.05$ sebesar 3.108. Karena $F_{\text {hitung }}>F_{\text {tabel }}$ maka koefisien arah regresi $X_{3}$ atas $X_{1}$ dan $X_{2}$ signifikan atau dengan kata lain $X_{1}$ dan $X_{2}$ secara serentak mempengaruhi $X_{3}$ secara signifikan pada $a=0.05$.

2) Motivasi Kerja terhadap Komitmen Organisasi

Dari hasil perhitungan Analisis Regresi di dapat tabel Anava sebagai berikut.

Tabel 5. Analisis Variansi Regresi $X_{4}$ atas $X_{3}$

\begin{tabular}{|c|c|c|c|c|c|}
\hline $\begin{array}{c}\text { Sumber } \\
\text { Variasi }\end{array}$ & $d k$ &.$I K$ & R.IK & $F_{\text {hit }}$ & $F_{\text {tab. }}$ \\
\hline Regresi & 1 & 4352,38 & 4352,38 & 151,5 & 3,96 \\
\hline Sisa & 83 & 2384,91 & 28,73 & & \\
\hline Total & 84 & 6737,29 & & & \\
\hline
\end{tabular}

Dari hasil perhitungan di atas diperoleh harga $F_{\text {hitung }}$ sebesar 151,472 sedangkan $F_{\text {tabel }}$ dengan $\mathrm{dk}$ pembilang 1 dan penyebut 83 pada taraf signifikansi $a=0,05$ sebesar 3,956 . Karena $F_{\text {hitung }}>F_{\text {tabel }}$ maka koefisien arah regresi $X_{4}$ atas $X_{3}$ signifikan atau dengan

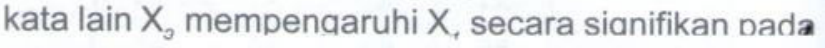
$a=0,05$.

\section{d. Uji Multikolinearitas}

Uji multikolinearitas digunakan apabila variabel bebasnya lebih dari satu, oleh karena itu yang diuji hanya regresi gaya kepemimpinan dan pemahaman prinsip dasar PLS terhadap motivasi kerja. Sebagai acuan apakah ada multikolinearitas atau tidak 
digunakan staistik VIF. Jika nilai VIF > 10 maka dapat dikatakan terdapat multikolinearitas dan sebaliknya.

Tabel 6. Tabel Variansi Inflasi Factor (VIF)

\begin{tabular}{|c|c|c|c|l|l|}
\hline \multirow{2}{*}{ Model } & \multirow{2}{*}{ SCB } & \multirow{2}{*}{$\mathrm{t}$} & \multirow{2}{*}{ Sig. } & \multicolumn{2}{|l|}{ Collinearity Statistics } \\
\cline { 5 - 6 } & & & Tolerance & VIF \\
\hline $\mathrm{X}_{1}$ & .402 & 3.578 & .001 & .305 & 3.279 \\
\hline $\mathrm{X}_{2}$ & .401 & 4.104 & .000 & .305 & 3.279 \\
\hline
\end{tabular}

a. Dependent Variable: $\mathrm{X} 3$

SCB = Standardized Coefficients Beta

Dari Tabel 6. dapat diketahui bahwa nilai VIF sebesar 3.279 yang artinya kurang dari 10 yang artinya pada regresi tersebut tidak terdapat Multikolinearitas.

Tabel 7. Tabel Variansi Inflasi Factor (VIF)

\begin{tabular}{|c|c|c|c|c|c|}
\hline \multirow{2}{*}{ Model } & \multirow{2}{*}{ SCB } & \multirow{2}{*}{$\mathrm{t}$} & \multirow{2}{*}{ Sig. } & \multicolumn{2}{|c|}{ Collinearity } \\
\cline { 4 - 6 } & & & Tolerance & VIF \\
\hline$X 1$ & 0.521 & 7.896 & .001 & 0.264 & 3.791 \\
\hline$X 2$ & 0.324 & 5.576 & .004 & 0.253 & 3.952 \\
\hline$X 3$ & 0.153 & 2.627 & .010 & 0.316 & 3.164 \\
\hline
\end{tabular}

E Dependent Variable: X4

SC8 = Standardized Coefficients Beta

Dari Tabel 7 dapat diketahui bahwa nilai VIF - =esar 3,279, 3,952 dan 3,164 yang artinya kurang = 10 yang artinya pada regresi tersebut tidak terdapat nutik olinearitas.

\section{zung-jian Hipotesis}

Pengujian hipotesis penelitian dilakukan dengan : analisis jalur. Hal ini dilakukan berdasarkan _ain penelitian yang telah dijelaskan sebelumnya. _tuk mengetahui pengaruh dari masing-masing a - car koefisien tiap lintasan dari variable eksogen E

- Tujuan pengujian analisis jalur adalah =. axe endogen sehingga dapat diketahui sejauh mana I =arm penelitian ini dibuat dua struktur model analisis \# = - inas kerja $\left(X_{3}\right)$ terhadap komitmen organisasi $\left(X_{4}\right)$. -2 pertitungan analisis jalur struktur satu dan -
Struktur 1 :

Gaya Kepemimpinan $\left(\mathrm{X}_{1}\right)$ dan Pemahaman Prinsip Dasar PLS $\left(\mathrm{X}_{2}\right)$ terhadap Motivasi Kerja $\left(\mathrm{X}_{3}\right)$

Tabel 8. Rangkuman Analisis Jalur Struktur 1

\begin{tabular}{|c|c|c|c|c|}
\hline Model & $\begin{array}{c}\text { Std. } \\
\text { Error }\end{array}$ & $\begin{array}{c}\text { Koefisien } \\
\text { Jalur }\end{array}$ & $t_{\text {hitung }}$ & $\begin{array}{c}\text { tabel } \\
\mathrm{\alpha}=0.05\end{array}$ \\
\hline $\mathrm{X}_{1}$ & 0.141 & 0.402 & 3.578 & 1.989 \\
\hline $\mathrm{X}_{2}$ & 0.204 & 0.461 & 4.104 & 1.989 \\
\hline
\end{tabular}

Variabel Endogen : Motivasi Kerja $\left(\mathrm{X}_{3}\right)$

Pada tabel di atas dapat digambarkan sebagai berikut.

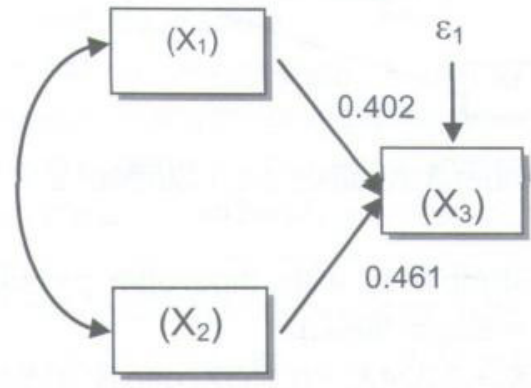

Gambar 2. Analisis Koefisien Jalur Struktur 1

Dari Gambar di atas diperoleh persamaan analisis jalur sebagai berikut :

$X_{3}=0,402 X_{1}+0,461 X_{2}$ dan $R^{2}=0,684$

Nilai $R^{2}$ sebesar 0.684 menggambarkan Kontribusi Gaya Kepemimpinan dan Pengetahuan Prinsip Dasar PLS terhadap Motivasi Kerja sebesar $68,4 \%$ sisanya $31,6 \%$ tidak masuk dalam model.

Dari Tabel 4.12 di atas dapat diketahui bahwa :

a). Gaya kepemimpinan berpengaruh langsung yang nyata terhadap motivasi kerja pengelola PKBM, hal ini ditunjukkan bahwa koefisien jalur gaya kepemimpinan terhadap motivasi kerja sebesar 0,402 mempunyai nilai thitung lebih besar dari pada $\mathrm{t}$ tabel dengan $\mathrm{a}=0,05$ atau $3,578>1.989$

b). Pengetahuan prinsip dasar PLS berpengaruh langsung yang nyata terhadap motivasi kerja pengelola PKBM, hal ini ditunjukkan bahwa koefisien jalur pengetahuan tentang prinsip dasar PLS terhadap motivasi kerja sebesar 0,461 mempunyai nilai t hitung lebih besar dari pada t tabel dengan $\mathrm{a}=0,05$ atau $4,104>1,989$.

Struktur 2 :

Gaya Kepemimpinan $\left(X_{1}\right)$, Pengetahuan Prinsip Dasar $\operatorname{PLS}\left(\mathrm{X}_{2}\right)$ dan Motivasi Kerja $\left(\mathrm{X}_{3}\right)$ terhadap Komitmen Organisasi $\left(\mathrm{X}_{4}\right)$

Jurnal IImiah VISI PTK-PNF - Vol. 5, No.1, Juni 2010 
Tabel 9. Rangkuman Analisis Jalur Struktur 2

\begin{tabular}{|c|c|c|c|c|c|}
\hline \multirow{2}{*}{ Model } & \multirow{2}{*}{$\begin{array}{l}\text { Std. } \\
\text { Error }\end{array}$} & \multirow{2}{*}{$\begin{array}{l}\text { Koefisien } \\
\text { Jalur }\end{array}$} & \multirow{2}{*}{ t-hitung } & \multicolumn{2}{|c|}{ tabel } \\
\hline & & & & 0.05 & 0.01 \\
\hline$X_{1}$ & 0.067 & 0.521 & 7.896 & 1.989 & 2.638 \\
\hline$x_{2}$ & 0.059 & 0.324 & 5.576 & 1.989 & 2.638 \\
\hline$X_{3}$ & 0.049 & 0.153 & 2.627 & 1.989 & 2.638 \\
\hline
\end{tabular}

Variabel Endogen : Komitmen Organisasi $\left(\mathrm{X}_{4}\right)$

Dari tabel di atas dapat digambarkan sebagai berikut :

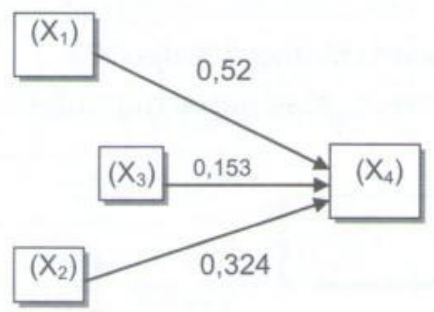

Gambar 3. Analisis Jalur Struktur 2

Dari Gambar di atas diperoleh persamaan analisis jalur sebagai berikut:

$$
X_{4}=0,521 X_{1}+0,324 X_{2}+0,153 X_{3} \text { dan } R^{2}=0,913
$$

Nilai $R^{2}$ sebesar 0,913 menggambarkan Kontribusi Gaya Kepemimpinan, Pengetahuan Prinsip dasar PLS dan Motivasi Kerja terhadap Komitmen Organisasi sebesar $91.3 \%$ sisanya $8,7 \%$ tidak masuk dalam model. Dari gambar di atas dapat diketahui bahwa:

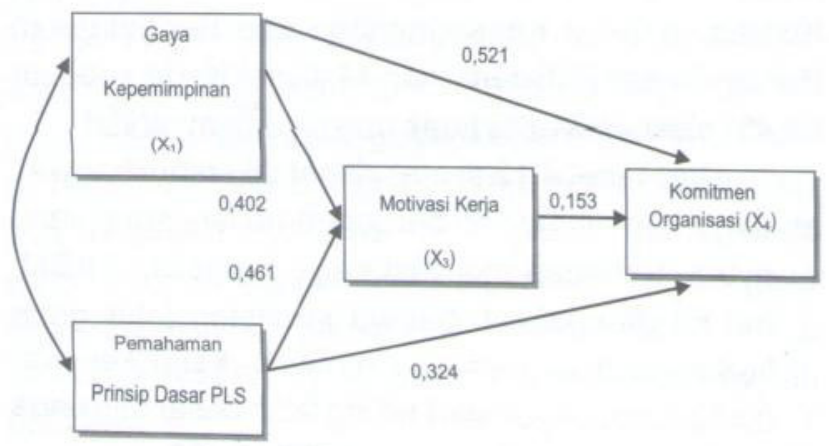

Gambar 4. Gabungan Analisis Jalur Struktur 1 dan Struktur 2

a) Gaya kepemimpinan dan motivasi kerja berpengaruh langsung yang nyata terhadap komitmen organisasi pengelola PKBM , hal ini ditujukkan bahwa koefisien jalur pengetahuan prinsip dasar PLS terhadap motivasi kerja sebesar 0,521 mempunyai nilai thitung lebih besar dari pada $t$ tabel dengan $a=0,05$ atau $7,896>1,989$.

b) Pengetahuan prinsip dasar PLS berpengaruh langsung yang nyata terhadap komitmen organisasi pengelola PKBM, hal ini ditunjukkan bahwa koefisien jalur pengetahuan prinsip dasar PLS terhadap motivasi kerja sebesar 0,324 mempunyai nilai thitung lebih besar dari pada $t$ tabel dengan $a=0,05$ atau $5,576>1,989$.

e) Motivasi kerja berpengaruh langsung yang nyata terhadap komitmen organisasi pengelola PKBM, hal ini ditunjukkan bahwa koefisien jalur motivasi kerja sebesar 0,153 mempunyai nilai t hitung lebih besar dari pada $t$ tabel dengan $a=0,05$ atau 2,627 $>1.989$.

Untuk mengetahui besarnya pengaruh tidak langsung gaya kepemimpinan terhadap komitmen organisasi dan besarnya pengaruh tidak langsung pengetahuan prinsip dasar PLS terhadap komitmen organisasi perlu menggabungkan analisis jalur 1 dan analisis jalur 2 sebagai berikut :

Dari gambar di atas dapat diringkas pada tabel di bawah ini.

Tabel 10. Rangkuman Analisis Jalur Struktur 2

\begin{tabular}{|c|c|c|c|}
\hline Pengaruh & $\begin{array}{c}\text { Pengaruh } \\
\text { Langsung } \\
(1)\end{array}$ & $\begin{array}{c}\text { Pengaruh Tidak } \\
\text { Langsung (2) }\end{array}$ & $\begin{array}{c}\text { Pengaruh } \\
\text { Total (1) }+(2)\end{array}$ \\
\hline$H_{1}: X_{1} \rightarrow X_{3}$ & 0,402 & - & 0.402 \\
\hline$H_{2}: X_{2} \rightarrow X_{3}$ & 0,461 & $-153=$ & 0.461 \\
\hline$H_{3}: X_{1} \rightarrow X_{4}$ & 0,521 & $\begin{array}{c}0.402 \times 0.153 \\
0.061\end{array}$ & 0.582 \\
\hline$H_{4}: X_{2} \rightarrow X_{4}$ & 0,324 & $\begin{array}{c}0.461 \times 0.153= \\
0.071\end{array}$ & 0.395 \\
\hline$H_{5}: X_{3} \rightarrow X_{4}$ & 0,153 & - & 0.153 \\
\hline
\end{tabular}

Dari tabel di atas dapat diketahui bahwa:

a) Gaya kepemimpinan mempunyai pengaruh tidak langsung terhadap komitmen organisasi sebesar 0,061 .

b) Pengetahuan prinsip dasar PLS mempunyai pengaruh tidak langsung terhadap komitmen organisasi sebesar 0,071.

\section{Pembahasan Hasil Penelitian}

Apabila diperhatikan dari hasil analisis penelitian di atas dapat disimpulkan bahwa gaya kepemimpinan yang digunakan pimpinan PKBM dalam mempengaruhi,' mengarahkan bawahan menuju pencapaian tujuan organisasi yang sudah ditetapkan dengan tepat secara signifikan berpengaruh langsung terhadap motivasi kerja. Tentu hal ini sangat rasional, karena pilihanpilihan perilaku dalam mempengaruhi dan mengarahkan bawahan akan memberikan hasil yang maksimal, sehingga seorang pemimpin akan memiliki semangat 
yang tinggi untuk lebih mendorong dirinya melakukan yang lebih baik lagi ke depan.

Seorang pemimpin akan semakin piawai menggunakan gaya kepemimpinan yang sangat sesuai dengan tingkat kematangan dan kondisi objektif dari bawahannya. Apalagi pada lembaga PKBM, sumber daya manusia yang bekerja di dalamnya pada umumnya berasal dari masyarakat yang di lingkungannya belum memiliki pekerjaan tetap ditambah lagi dengan latar belakang pendidikan yang tidak terlalu tinggi, sehingga suasana kekeluargaan dan rasa memiliki lembaga perlu dipelihara dengan baik.

Begitu juga dengan hasil uji hipotesis pengetahuan prinsip dasar PLS berpengaruh langsung terhadap motivasi kerja secara signifikan juga terbukti. Artinya pengetahuan pimpinan PKBM tentang konsep, prosedur, dan praktik pendidikan nonformal akan berpengaruh langsung terhadap motivasi dalam mengelola lembaganya. Barangkali hal ini sesuatu yang sangat rasional, karena di saat seseorang termasuk di dalamnya pimpinan PKBM menguasai secara kognitif tentang apa yang menjadi tugasnya, maka seseorang tersebut akan semakin percaya diri dan sekaligus akan meningkatkan motivasinya dalam mengelola programprogram pendidikan nonformal. Dengan demikian, dapat disimpulkan bahwa secara bersama-sama terbukti bahwa gaya kepemimpinan dan pengetahuan prinsip dasar PLS yang dimiliki oleh pimpinan PKBM secara signifikan berpengaruh langsung terhadap peningkatan motivasi kerja.

Berdasarkan hasil analisis terbukti pada motivasi kerja berpengaruh langsung terhadap komitmen organisasi pengelola (pimpinan) PKBM. Berdasarkan hasil analisis, terbukti bahwa komitmen organisasi dipengaruhi oleh motivasi kerja. Semakin tinggi motivasinya dalam bekerja maka semakin tinggi pula komitmen organisasi dalam mengelola PKBM.

Berdasarkan hasil penelitian juga dapat disimpulkan bahwa gaya kepemimpinan berpengaruh langsung terhadap komitmen organisasi pengelola PKBM. Artinya bahwa komitmen organisasi dipengaruhi oleh pilihan-pilihan perilaku yang digunakan oleh seorang pemimpin dalam mempengaruhi dan memberdayakan anggota untuk mencapai tujuan organisasi (PKBM) yang sudah ditetapkan. Begitu juga, pengetahuan prinsip dasar PLS dapat berpengaruh langsung terhadap komitmen organisasi pengelola PKBM. Ini juga berarti bahwa komitmen organisasi secara langsung dipengaruhi oleh pengetahuan prinsip dasar PLS yang dimiliki oleh para pengelola PKBM.

Dengan demikian tentu dapat ditarik kesimpulan bahwa pilihan-pilihan pola perilaku yang digunakan oleh seorang pimpinan $\mathrm{PKBM}$, pengetahuan tentang semua informasi yang berkenaan dengan prinsip dasar PLS serta motivasi kerja yang tinggi secara bersama-sama berpengaruh langsung terhadap tingginya komitmen organisasi yang dimiliki oleh pengelola PKBM.

\section{Keterbatasan Penelitian}

Walau upaya yang dilakukan dalam penelitian ini sudah memenuhi persyaratan-persyaratan ilmiah, namun dalam banyak hal masih terdapat kekurarngan apabila dilihat dari sudut:

Pertama, penelitian ini hanya melihat pengaruh tiga variabel eksogen terhadap komitmen organisasi (variabel endogen) para pengelola/pimpinan PKBM yang pengaruhnya seperti hasil penelitian ini menunjukkan signifikan. Artinya bahwa komitmen organisasi pimpinan PKBM dipengaruhi oleh gaya kepemimpin, pengetahuan tentang prinsip dasar PLS, dan motivasi kerja. Sementara itu, masih ada variabel-variabel lain yang memang tidak terjangkau oleh penelitian ini akan ikut juga memberikan pengaruh.

Kedua, instrumen yang digunakan dalam penelitian ini dalam bentuk kuesioner dan tes yang sudah diuji validitas dan reliabilitasnya, sehingga diyakini instrumen ini layak untuk digunakan dalam pengumpulan data dan informasi. Namun sebaliknya, para responden dalam memberikan informasi melalui instrumen ini bisa saja dalam kondisi tidak siap, banyak masalah atau memang tidak punya kemauan untuk mengisi atau menjawab instrumen yang diberikan, sehingga diasumsikan isian instrumen ada yang bias.

Ketiga, indikator-indikator yang digunakan untuk mengukur semua variabel masih mungkin saja belum lengkap, sehingga masih membutuhkan waktu dan cara untuk mengembangkan indikator tersebut, karena diyakini bahwa semakin banyak indikator-indikator yang bisa dikembangkan, maka akan semakin dekat karakteristik yang dimiliki oleh setiap variabel.

\section{KESIMPULAN}

\section{Kesimpulan}

Berdasarkan analisis data dan pembahasan hasil penelitian di atas, maka diperoleh beberapa hasil temuan penelitian sebagai berikut a) gaya kepemimpinan pengelola PKBM berpengaruh langsung terhadap motivasi kerja, b) pengetahuan tentang prinsip dasar 
PLS dari pengelola PKBM berpengaruh langsung terhadap motivasi kerja, c) motivasi kerja berpengaruh langsung terhadap komitmen organisasi para pengelola PKBM, d) gaya kepemimpinan pengelola PKBM berpengaruh langsung terhadap komitmen organisasi, e) pengetahuan prinsip dasar PLS dari pengelola PKBM berpengaruh langsung terhadap komitmen organisasi, f) gaya kepemimpinan pengelola PKBM berpengaruh tidak langsung terhadap komitmen organisasi melalui motivasi kerja, dan g) pengetahuan konsep dasar PLS dari pengelola PKBM berpengaruh tidak langsung terhadap komitmen organisasi melalui motivasi kerja.

Dari uraian di atas maka dapat ditarik kesimpulan bahwa gaya kepemimpinan atau pola perilaku atau cara yang dipilih oleh seorang pemimpin PKBM dalam menjalankan roda organisasi turut secara signifikan mempengaruhi peningkatan motivasi dalam menjalankan organisasi PKBM dan sekaligus memberikan pengaruh terhadap komitmen organisasi (kesadaran berada dalam organisasi tetap tinggi).

Di samping itu, dapat juga disimpulkan bahwa pengetahuan tentang prinsip dasar PIS (pondidikan nonformal) bagi pemimpin atau pengelola PKBM juga memberikan pengaruh langsung terhadap motivasi kerja dan pengaruh tidak langsung terhadap komitmen organisasi para pengelola PKBM melalui motivasi kerja.

Di sisi lain dapat juga disimpulkan bahwa motivasi kerja tinggi yang dimiliki oleh para pengelola PKBM memberikan pengaruh langsung terhadap komitmen organisasi (kesadaran yang tinggi dan tetap dalam organisasi) dan semua kesimpulan di atas memberikan kesimpulan yang sesuai dengan acuan teoretik yang dikemukakan oleh Qolquitt at.al dalam bukunya Orgazational Behavior terbitan 2009. Implikasi

Berdasarkan kesimpulan hasil penelitian di atas, maka ada beberapa implikasi baik secara teoretis, praktis, dan implementasi kebijakan.

Untuk implemen-tasi teoretik, hasil penelitian ini diharapkan memberikan informasi ilmiah dan fakta empiris yang dapat berguna dalam tatanan akademis, terutama dalam khasanah pengembangan keilmuan pendidikan nonformal.

Sedangkan dari sudut implikasi praktis, model yang diuji melalui aktivitas penelitian berpeluang dapat dijadikan acuan oleh tenaga kependidikan PLS terutama para pengelola PKBM untuk meningkatkan komitmen pengelola PKBM dengan peduli dan apresiatif pada faktor-faktor gaya kepemimpinan, pemahaman prinsip dasar PLS, dan motivasi kerja untuk mengin- tegrasikannya dalam aktivitas pembelajaran PLS (pendidikan nonformal) yang komprehensif.

Sedangkan pada tatanan kebijakan hasil penelitian ini dapat dijadikan sebagai bahan pertimbangan untuk pengembangan institusi PKBM di masa yang akan datang dengan memperhatikan berbagai faktor yang secara empiris berpengaruh terhadap keberlangsungan PKBM itu sendiri.

\section{Saran}

Ada bebarapa saran yang perlu dipertimbangkan dalam upaya memelihara kesinambungan proses pengelolaan PKBM pada masa yang akan datang, terutama pada aspek pengelola atau para pemimpin PKBM. Saran-saran tersebut adalah sebagai berikut.

Bagi pemerintah daerah, perlu mendukung terlaksananya kegiatan PKBM. Dukungan tersebut dapat dalam bentuk regulasi, program peningkatan kemampuan para pengelola atau pemimpin dalam berbagai training, dan dukungan dana yang memadai serta fasilitas lainya. Dengan demikian, dapat diperkirakan bahwa PKBM yang ada di DKI Jakarta khususnya dan provinsi provwinsi lain di soluruth tarmath air, di samping tumbuhnya kesadaran masyarakat untuk berpartisipas dalam bidang pendidikan (pendidikan nonformal sekaligus juga menghasilkan masyarakat yang mand

Bagi para pengelola PKBM, harus sesering mungkin punya kemauan yang kuat untuk meningkataketerampilan dan pengetahuan dalam berbagai bidang terutama dalam manajemen PKBM seperti memaham berbagai pola perilaku sebagai seorang pemimpiPKBM melalui pelatihan-pelatihan kepemimpinan dart lembaga yang kompeten, menguasai pengetahuanpengetahuan tentang prinsip dasar pendidikan luat sekolah atau pendidikan nonformal yang memang harus selalu disesuaikan dengan perkembangan ilmu itu sendiri. Di samping itu, para pengelola juga harus mempelajari pengetahuan-pengetahuan tentang kewirausahaan baik dari sudut teoretik maupun dari sudut implementatif antara lain dapat dilakukan pelatihan Achievement Motivation Training (AMT) dan lain-lain

Bagi Perguruan Tinggi, memiliki sumber daya manusia yang mumpuni serta fasilitas pendukung yang cukup terutama kemampuan dalam bidang penelitian. maka perlu dilakukan upaya penelitian lanjutan yang mendalam dan hasilnya uaja ı memverıkan jalan keluár terhadap persoalan-persoalan pengembangan pendidikan berbasis masyarakat yang berlangsung pada jalur pendidikan nonformal bisa berjalan dengan baik dan bermutu khususnya di perkotaan seperti DKI Jakarta ini. 


\section{DAFTAR PUSTAKA}

Anderson, L.W., \& Krathwohl, D.R. (Eds). (2001). A taxonomy for learning, teaching, and assessing: A revision of Bloom's taxonomy of educational objectives. A bridged edition. New York: Longman.

Baron, R.A. \& Greenberg, J. (1990). Behavior in organization: Understanding and managing the human side of work. (Third edition). Allyn \& Bacon.

Davis, K. \& Newstrom, J.W. (1989). Organizational behavior: Human behavior at work. (Eight edition). New York: McGraw Hill.

Davis, K. \& Newstrom, J.W. (1998). Organizational behavior: Human behavior at work. (Ten edition). New York: McGraw Hill.

Donovan, J.J. (1990). Work motivation: The handbook of industrial, work, and, organizational psychoIogy. London: Sage Publication.

Jason, \& Colquitt, et.al. (2009). Organizational behavior improving performance and commitment in the workplace. New York: McGraw-Hill.
Leithwood, K. \& Louis, K.S. (Eds). (1998). Organizational learning in schools. Downmington. PA: Sweets and Zeitlinger.

Luthans, F. (1995). Organizational behavior. Seventh edition. New York: Mc-Graww Hill

Luthans, F. (2006). Perilaku organisasi. Edisi ke 10 Bahasa Indonesia. Yogyakarta: Penerbit ANDI.

Robin, S. \& Timothy, A.J. (2007). Organizational behavior. New Jersey: Pearson Education Inc.

Shaw, J.D., Delery, J.E. \& Abdulla M.H.A. (2003). Organizational commitment and performance among guest workers and citizens of an Arab country. Journal of Business Research. Vol. 56. Number 12. December 2003.

Steers, R.M and Porter, W.L. (2007). Motivation and work behavior. Highttown, New Jersey: McGraw Hill Inc.

Sudjana S.D. (2004). Pendidikan nonformal, wawasan perkembangan filsafat teori pendukung asas. Bandung: Falah Production. 